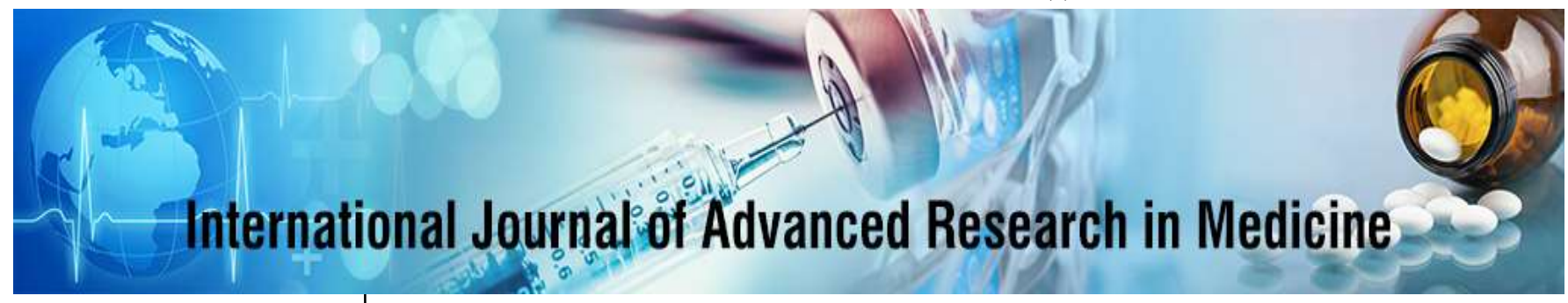

E-ISSN: 2706-9575

P-ISSN: 2706-9567

IJARM 2021; 3(1): 272-274

Received: 11-12-2020

Accepted: 24-01-2021

Dr. Nagendra Singh Chauhan Associate Professor, Department of Medicine, FH Medical College and Hospital, Tundla, Firozabad, Uttar Pradesh, India
Corresponding Author: Dr. Nagendra Singh Chauhan Associate Professor, Department of Medicine, FH Medical College and Hospital, Tundla, Firozabad, Uttar Pradesh, India

\section{Assessment of thyroid dysfunction in beta thalassemia patients}

\author{
Dr. Nagendra Singh Chauhan \\ DOI: https://doi.org/10.22271/27069567.2021.v3.i1e.150
}

\begin{abstract}
Background: Thalassemia is the most common inherited monogenic disorder in the world. The present study was conducted to assess thyroid dysfunction in thalassemia patients.

Materials \& Methods: 84 children with beta thalassemia major of both genders were assessed for serum total thyroxine (T4), thyroid-stimulating hormone (TSH) and Serum ferritin levels were obtained. TSH and T4 concentration were analyzed by ELISA.

Results: There were 64 euthyroid and 20 hypothyroid patients. 40 male and 24 females euthyroid patients and 12 males and 8 hypothyroid patients. The difference was significant $(P<0.05)$. The amount of blood transfused was $230.4 \mathrm{ml} / \mathrm{kg}$ and $272 \mathrm{ml} / \mathrm{kg}$, serum ferritin $(\mathrm{ng} / \mathrm{ml})$ level was 1972.5 and 28.16, serum TSH $\mu \mathrm{IU} / \mathrm{ml}$ was 3.05 and 7.14 , serum free T4 (pmol/l) was 12.7 and 10.6 and serum free T3 (pmol/l) level was 6.14 and 4.52 in euthyroid and hypothyroid patients. The difference was significant $(P<0.05)$.

Conclusion: Severity of thyroid dysfunction in thalassemia patients was variable.
\end{abstract}

Keywords: Thyroid dysfunction, thalassemia, children

\section{Introduction}

Thalassemia is the most common inherited monogenic disorder in the world. It is an autosomal recessive disorder of two major types - alpha and beta - depending on the affected gene for globin chain ${ }^{[1]}$. The average prevalence of beta thalassemia carriers is $3 \%$ 4\%, which translates to 35-45 million carriers in our multi-ethnic and culturally and linguistically diverse population of 1.21 billion people, which also includes around $8 \%$ of tribal groups according to the Census of India 2011. Several ethnic groups have a much higher prevalence $(4 \%-17 \%)$ with an estimated 100,000 patients with thalassemia ${ }^{[2]}$.

Beta-thalassemia is one of the most common genetic diseases in Iran. Iran has about 20,000 homozygote $\beta$-thalassaemia patients and 3,750,000 carriers. The combination of blood transfusion and chelation therapy has dramatically prolonged the life expectancy of these patients, thus transforming thalassaemia from a rapidly fatal disease of childhood to a chronic disease compatible with a prolonged life ${ }^{[3]}$. On the other hand frequent blood transfusions, iron overload, poor compliance to therapy and chronicity of the disease have in turn contributed to a whole spectrum of complications including cardiac problems, hypogonadism, diabetes mellitus, hypothyroidism, hypoparathyroidism and other endocrine and metabolic problems in adolescents and young adults suffering from thalassaemia major ${ }^{[4]}$. Hypothyroidism is the second most common endocrine disorder after hypogonadism, having been reported in 5.6\%-17\% of patients. Iron deposition is the main cause of damage to the endocrine glands, directly or through the hypothalamic-pituitary axis. High ferritin levels, poor compliance with chelation, and splenectomy increase the risk of endocrinopathies in thalassemics ${ }^{[5]}$. The present study was conducted to assess thyroid dysfunction in thalassemia patients.

\section{Materials \& Methods}

The present study was conducted among 84 children with beta thalassemia major of both genders. Inclusion of patients was done after obtaining their written consent.

Data such as name, age, gender etc. was recorded. A thorough clinical examination was performed. Serum total thyroxine (T4), thyroid-stimulating hormone (TSH) and Serum ferritin levels were obtained. TSH and T4 concentration were analyzed by ELISA. Hypothyroidism was defined by a TSH level $>4 \mu \mathrm{IU} / \mathrm{ml}$, T4 levels $<4 \mu \mathrm{g} / \mathrm{dl}$ was defined as 
decreased. The thyroid function status of the patients was classified as subclinical hypothyroidism (increased TSH, normal T4, and T3) and overt (increased TSH, decreased T4 and/or T3) hypothyroidism primary. Results were tabulated and subjected to statistical analysis. $\mathrm{P}$ value less than 0.05 was considered significant.

\section{Results}

Table 1: Distribution of patients

\begin{tabular}{|c|c|c|c|}
\hline Parameters & Euthyroid & Hypothyroid & P value \\
\hline Number & 64 & 20 & 0.02 \\
\hline Male & 40 & 12 & \multirow{2}{*}{0.05} \\
\hline Female & 24 & 8 & \\
\hline
\end{tabular}

Table I, graph I shows that there were 64 euthyroid and 20 hypothyroid patients. 40 male and 24 females euthyroid patients and 12 males and 8 hypothyroid patients. The difference was significant $(P<0.05)$.

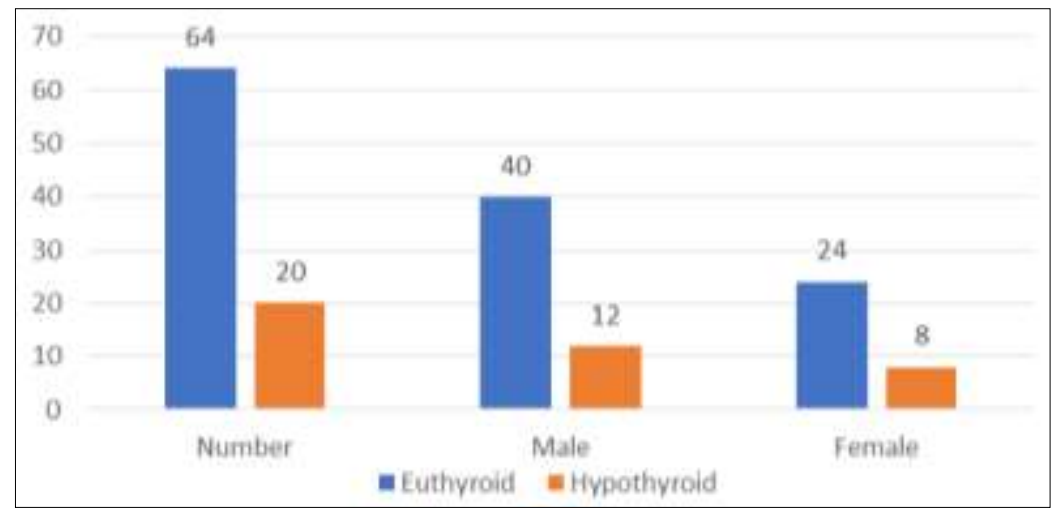

Graph 1: Distribution of patients

Table 2: Assessment of parameters

\begin{tabular}{|c|c|c|c|}
\hline Parameters & Euthyroid & Hypothyroid & P value \\
\hline Amount of blood transfused $(\mathrm{ml} / \mathrm{kg} /$ year $)$ & 230.4 & 272.0 & 0.01 \\
\hline Serum ferritin $(\mathrm{ng} / \mathrm{ml})$ & 1972.5 & 28.16 & 0.01 \\
\hline Serum TSH $\mu \mathrm{IU} / \mathrm{ml}$ & 3.05 & 7.14 & 0.01 \\
\hline Serum free $\mathrm{T}_{4}(\mathrm{pmol} / \mathrm{l})$ & 12.7 & 10.6 & 0.05 \\
\hline Serum free $\mathrm{T}_{3}(\mathrm{pmol} / \mathrm{l})$ & 6.14 & 4.52 & 0.02 \\
\hline
\end{tabular}

Table I shows that amount of blood transfused was 230.4 $\mathrm{ml} / \mathrm{kg}$ and $272 \mathrm{ml} / \mathrm{kg}$, serum ferritin (ng/ml) level was 1972.5 and 28.16 , serum TSH $\mu \mathrm{IU} / \mathrm{ml}$ was 3.05 and 7.14 , serum free T4 (pmol/l) was 12.7 and 10.6 and serum free T3 (pmol/l) level was 6.14 and 4.52 in euthyroid and hypothyroid patients. The difference was significant $(P<$ $0.05)$.

\section{Discussion}

Clinically overt manifestations of hypothyroidism occur late in life, and therefore most of the available studies have been done in adults ${ }^{[6]}$. Only a very few pediatric studies are available. In India, the cost of chelation precludes ideal therapy for majority of the patients, and the compliance with transfusion is often not optimal ${ }^{[7]}$. Therefore, there is a possibility that there might be a high prevalence of thyroid dysfunction in such patients, and there are high chances of it manifesting at an age earlier than that projected in Western studies ${ }^{[8]}$. The commonest form of thyroid dysfunction, seen in thalassaemics, is subclinical hypothyroidism due to abnormalities of the thyroid gland which, leads to insufficient production of thyroid hormones. However, the frequency of hypothyroidism varies depending on the region, quality of management and treatment protocols ${ }^{[9]}$. The present study was conducted to assess thyroid dysfunction in thalassemia patients.
In present study, there were 64 euthyroid and 20 hypothyroid patients. 40 male and 24 females euthyroid patients and 12 males and 8 hypothyroid patients. Singhal et al. ${ }^{[10]}$ in their study12 children were enrolled in the study and thyroid function tests along with serum Ferritin levels were done for all the subjects. Out of a total of 112 children, 82 were Euthyroid (73.2\%) and 30 were Hypothyroid (26.8\%). The mean serum Ferritin, serum TSH, serum Free T4 and serum Free T3 in Euthyroid children were 1975.4 \pm $706.2(\mathrm{ng} / \mathrm{ml}), 3.23 \pm 0.93(\mu \mathrm{IU} / \mathrm{ml}), 12.8 \pm 2.3(\mathrm{pmol} / \mathrm{l})$ and $6.12 \pm 1.4(\mathrm{pmol} / \mathrm{l})$ respectively. Whereas in Hypothyroid children the mean serum Ferritin, serum TSH, serum Free T4 and serum Free T3 were $2842.9 \pm 1095.2(\mathrm{ng} / \mathrm{ml}), 7.05 \pm$ $1.91(\mu \mathrm{IU} / \mathrm{ml}), 10.55 \pm 2.0(\mathrm{pmol} / \mathrm{l})$ and $4.49 \pm 1.2(\mathrm{pmol} / \mathrm{l})$ respectively.

We found that amount of blood transfused was $230.4 \mathrm{ml} / \mathrm{kg}$ and $272 \mathrm{ml} / \mathrm{kg}$, serum ferritin (ng/ml) level was 1972.5 and 28.16, serum TSH $\mu \mathrm{IU} / \mathrm{ml}$ was 3.05 and 7.14 , serum free T4 (pmol/l) was 12.7 and 10.6 and serum free T3 (pmol/l) level was 6.14 and 4.52 in euthyroid and hypothyroid patients. Hashemizadeh et al. [11] carried out 400 samples of thalassemia major patients. Thyroid function and iron load status were evaluated by measuring the serum total triiodothyronine (T4), thyroid-stimulating hormone (TSH) and ferritin levels. TSH and T4 concentrations were estimated by enzyme-linked immunosorbent assay (ELISA). 
Primary hypothyroidism was defined by a TSH level $>4 \mu \mathrm{IU} / \mathrm{ml}$. Subclinical hypothyroidism was seen in $7 \%$ patients. All of them had normal T4 levels with elevated TSH levels, consistent with a diagnosis of subclinical hypothyroidism. Mean age of hypothyroid patients was 10.2 \pm 2.5 years. Frequency of hypothyroidism was associated with increased serum ferritin levels $(\mathrm{p}=0.037)$.

De Virgiliis et al. ${ }^{[12]}$ have reported primary hypothyroidism in $18(25.7 \%)$ out of 70 patients. Of these, 17 had normal T4 levels with elevated TSH levels consistent with a diagnosis of Subclinical hypothyroidism whereas only one patient showed a decreased T4 level with elevated TSH (overt hypothyroidism). Mean age of hypothyroid patients was 9.2 \pm 2.6 years. Frequency of hypothyroidism was associated with increased serum ferritin levels. Primary hypothyroidism occurs in a significant proportion of thalassaemia major patients in the absence of obvious clinical signs of hypothyroidism. Regular follow-up for early detection and timely treatment of such complications could improve the quality of life of these patients.

The precise mechanism by which iron overload causes tissue damage is not completely understood, though it is suggested that tissue iron deposits act at the cellular level causing damage via free radical formation and lipid peroxidation resulting in mitochondrial, lysosomal and sarcolemmal membrane damage ${ }^{[13]}$. In the thyroid gland, this affects the production of thyroid hormones and manifests as varying degrees of primary hypothyroidism. Hence, it is postulated that higher serum ferritin levels predispose to a greater risk of developing endocrinopathies like hypothyroidism. It has been suggested that thyroid dysfunction may be reversible by intensive chelation ${ }^{[14]}$.

\section{Conclusion}

Authors found that severity of thyroid dysfunction in thalassemia patients was variable.

\section{References}

1. Shamshirsaz AA, Bekheirnia MR, Kamgar M, Pourzahedgilani N, Bouzari N, Habibzadeh M, et al. Metabolic and endocrinologic complications in betathalassemia major: a multicenter study in Tehran. BMC Endocr Disord 2003;12:3(1):4.

2. Karimi M, Jamalian N, Yarmohammadi H, Askarnejad A, Afrasiabi A, Hashemi A. Premarital screening for $\beta$ thalassaemia in Southern Iran: options for improving the programme. J Med Screen 2007;14:62-66.

3. Khan FR. Thalassaemia: Still a challenge. Gomal J Med Sci 2006;4:47-8.

4. Satwani H, Raza J, Alam M, Kidwai A. Endocrine Complications in Thalassaemias: Frequency and Association with Serum Ferritin Levels. Pak Paediat Assoc J 2005; 29:113-9.

5. Vullo C, De Sanctis V, Katz M, Wonke B, Hoffbrand $\mathrm{AV}$, Bagni $\mathrm{B}$, et al. Endocrine abnormalities in thalassemia. Ann N Y Acad Sci 1990;612:293-310.

6. Agarwal MB. Advances in management of thalassaemia. Indian Paediatrics 2004;41:989-92.

7. Costin G, Kogut MD, Hyman CB, Ortega JA. Endocrine abnormalities in thalassemia major. Am $\mathbf{J}$ Dis Child 1979;133(5):497-502.

8. Zervas A, Katopodi A, Protonotariou A, Livadas S, Karagiorga M, Politis C, et al. Assessment of thyroid function in two hundred patients with beta-thalassemia major. Thyroid 2002;12(2):151-4.

9. Landau H, Matoth I, Landau-Cordova Z, Goldfarb A, Rachmilewitz EA, Glaser B. Cross-sectional and longitudinal study of the pituitary thyroid axis in patients with thalassaemia major. Clin Endocrinol (Oxf) 1993;38(1):55-61.

10. Singhal A, Goyal H. Thyroid dysfunction in beta thalassemia major patients. Thyroid Res Pract 2020;17:70-5.

11. Hashemizadeh H, Noori R. Assessment of hypothyroidism in children with beta-thalassemia major in north eastern Iran. Iranian Journal of Pediatric Hematology and Oncology 2012;2(3):123-7.

12. De Virgiliis S, Sanna G, Cornacchia G, Argiolu F, Murgia V, Porcu M, et al. Serum ferritin, liver iron stores, and liver histology in children with thalassaemia. Arch Dis Child 1980;55(1):43-5.

13. Cohen A, Cohen IJ, Schwartz E. Scurvy and altered iron stores in thalassemia major. $\mathrm{N}$ Engl $\mathrm{J}$ Med 1981;304(3):158-60.

14. Worwood M, Cragg SJ, Jacobs A, McLaren C, Ricketts C, Economidou J. Binding of serum ferritin to concanavalin A: patients with homozygous beta thalassaemia and transfusional iron overload. $\mathrm{Br} \mathrm{J}$ Haematol 1980;46(3):409-16. 